AperTO - Archivio Istituzionale Open Access dell'Università di Torino

\title{
Wilhelmine of Bayreuth and the German Enlightenment
}

\section{This is a pre print version of the following article:}

Original Citation:

\section{Availability:}

This version is available http://hdl.handle.net/2318/1808083

since 2021-10-01T10:33:28Z

Publisher:

Oxford University Press

Terms of use:

Open Access

Anyone can freely access the full text of works made available as "Open Access". Works made available under a Creative Commons license can be used according to the terms and conditions of said license. Use of all other works requires consent of the right holder (author or publisher) if not exempted from copyright protection by the applicable law. 


\section{PART III \\ WOMEN AND THE \\ GREAT DEBATES}




\title{
5 \\ Wilhelmine of Bayreuth and the German Enlightenment
}

\author{
Paola Rumore
}

\begin{abstract}
The Margravine of Bayreuth, a princess of great intellect and worth, Frederick's older sister, and a true sister of his in thought and in heart, married to the Hereditary Prince of Bayreuth and sadly out of place in that pretty court, set out one day in order to relieve the tedium of her existence to write down all the sufferings, all the domestic persecutions, that she had known before, and after, her marriage. ${ }^{1}$
\end{abstract}

C5.P2 With these words in his Portraits Littéraires (1843/1876-78), the French historian and literary critic Sainte-Beuve introduces both the figure of the Princess of Prussia, Friderike Sophie Wilhelmine (1709-1758) and her literary activity. ${ }^{2}$ On the one hand, the passage points out the close relationship of the princess with her brother Frederick the Great, a closeness testified by their thirty years-long correspondence, which today is still an important source of information concerning the intellectual and the political life of the king of Prussia. ${ }^{3}$ On the other hand, Sainte-Beuve's description insists on the feeling of inadequacy that characterizes Wilhelmine's private and public life, which comes out in a very clear way in the only work she wrote: Les Memoires de ma vie (Memoires of my Life), a detailed narration of her youth at the Prussian court and of her time in Bayreuth, composed in the last decade of her life, between 1748 and $1758 .{ }^{4}$

1 Sainte-Beuve, Portraits of the Eighteenth Century. Historic and Literary, p. 353.

${ }^{2}$ For an initial general portrait of the princess cf. Hirsch, 'Wilhelmine'. A very insightful biography is Oster, Wilhelmine von Bayreuth. Das Leben der Schwester Friedrichs des Großen; cf. also Wintersteiner, Meine Schwester in Bayreuth. Markgräfin Wilhelmine und ihr Bruder Friedrich der Große-ein biographischer Roman; and Weber-Kellermann (ed.), Eine preussische Königstochter: Glanz und Elend am Hofe des Soldatenkönigs in den Memoiren der Markgräfin Wilhelmine von Bayreuth.

${ }^{3}$ After the pioneering edition by Burrell (Thoughts for enthusiasts at Bayreuth) the correspondence between Frederick and Wilhelmine has been published by Volz in Friedrich der Große und Wilhelmine von Baireuth, Vol. 1: Jugendbriefe 1728-1740; and Vol. 2: Briefe der Königszeit 1740-1758. Some of the letters are also published in Heckmann-Janz and Kretschmer (eds.), .... so lange wir zu zweit sind.' Friedrich der Grosse und Wilhelmine Markgräfin von Bayreuth in Briefen; in the two volumes edited by Berger and Wassermann, Nichts Neues aus Bayreuth. Briefe der Markgräfin Wilhelmine an Friedrich II. und Voltaire; and in Bagatellen aus Berlin. Briefe Friedrichs II. an Wilhelmine von Bayreuth.

${ }^{4}$ Mémoires de Frédérique Sophie Wilhelmine. A German translation by Annette Kolb is now available with the title Die Memoiren. The following quotations are from this edition. 
C5.P3 Friderike Sophie Wilhelmine was born on 3 July 1709 in Berlin as the eldest daughter of Frederick William I, since 1713 the king of Prussia, and Sophia Dorothea of Hanover, the daughter of the then-king of England, George I. Only three years older than her brother Frederick she shared with him the deepest feeling of inadequacy towards the expectations of their father, the so-called 'Soldier King', whose strict military discipline was also reflected in their education which left little space for cultural ambitions and for the natural development of the manifest artistic and literary talents of the siblings. The years Wilhelmine spent at the Prussian court were not the easiest; in the Memoires she offers a clear and touching description of that time, including of the mistreatment she suffered at the hands of her governess during her early years, as well as of the several conflicts with her father. One such conflict that deserves mention is her involvement in the attempted, and failed, desertion of her younger brother Frederick in 1730 which resulted in both of them suffering severe punishments. ${ }^{5}$ The hostile atmosphere the siblings experienced in the relationship with their father, along with the limited support provided by their mother, strengthened their feeling of solidarity and complicity so that they developed a reciprocal affectionate devotion that is clearly perceivable in their private correspondence and in Wilhelmine's memoirs. Recalling the times of her childhood, around the age of eight, she already remembers that while all her time was taken up with her masters, her 'only recreation was to see [her] brother. Never was an affection equal to [theirs].'

C5.P4 Still, the extensive narration of her personal memories, although a crucial source of information about the private and public life at the court of the king of Prussia, was not meant to be published. Far from it being her intention to provide a direct account of the behind-the-scenes life of the Prussian royal family, Wilhelmine rather undertook to compose her Memoires as a source of personal consolation and relief:

C5.P5 I write for my own amusement, and do not expect that these memoirs will ever be printed; perhaps I may sacrifice them to the fire some day, perhaps I shall give them to my daughter; in fact, I still do not know. I say again, I write solely for my own amusement, and I take pleasure in concealing nothing of all that has ever happened to me, even my most secret thoughts. ${ }^{7}$

C5.P6 Wilhelmine often repeats that those pages were only meant as an escape from the tedium and sufferings of her domestic existence. And in fact, shortly before her

\footnotetext{
${ }^{5}$ A detailed report of the episode can be read in Wilhelmine von Bayreuth, Die Memoiren, pp. 193-236.

${ }^{6}$ Ibid., p. $45 . \quad{ }^{7}$ Ibid., pp. $473 f$.
} 
death, she left the manuscript to her personal physician and main advisor at the Bayreuth court, Daniel de Superville (1696-1773) ${ }^{8}$ - a man, she says in her Memoires, of exceptional intellectual liveliness and gifted with the best esprit français-in whose Nachlass they were finally found and only published a halfcentury after Wilhelmine's death, in 1810. The mix of tasteful anecdotes and spicy revelations concerning life at the Prussian court is the reason for the commercial success of the work, which was immediately translated into English and German, and now and then even revised and expanded with additional material. ${ }^{9}$ It is only thanks to an extensive philological investigation that it has become possible in recent years to read the original work as it proceeded from the pen of the Princess herself. $^{10}$

C5.P7 Beside the correspondence with her brother the king and with some other familiar characters of the time-Voltaire first and foremost-the Memoires represent the main source for our understanding of Wilhelmine's active cultural life: they reveal a deep passion for fine arts in general, and especially for music-she was a lutenist, and wrote an opera, Argenore, performed in 1740 for her husband's birthday, as well as some chamber music that still survives - for literature, and last but not least for philosophy. In Bayreuth, she expanded the already impressive book collection she had begun during her adolescence in Berlin. The more than 4,000 volumes in her private library, almost all in French, include translations of Greek and Roman classics, and original literary, theological, and philosophical works, among which one can find, beside Machiavelli and Montaigne, the works of the protagonists of the then-current philosophical debates: Fontenelle, Montesquieu, Prémontval, Voltaire, Rousseau, La Mettrie, Algarotti, and even by the Marquis d'Argens. ${ }^{11}$ According to Wilhelmine's will, after her death the collection was brought to Erlangen and is still today in the catalogue of the library of

\footnotetext{
${ }^{8}$ On Daniel de Superville cf. Pfeiffer, 'Daniel de Superville'; on his contribution to the foundation of the University in Erlangen cf. Rüthnick, 'Daniel de Superville, der Gründer der Universität Erlangen. Beiträge zur Geschichte seines Lebens'. On his relationship with Wilhelmine cf. WitternSterzel, Wilhelmine von Bayreuth und Daniel de Superville: Vorgeschichte und Frühzeit der Erlangener Universität.

${ }^{9}$ On the destiny of the manuscript cf. Droysen, 'Die Handschriftliche Überlieferung der "Mémoires de ma vie" der Markgräfin Wilhelmine von Bayreuth'.

${ }^{10}$ A German translation (up to 1733) was published in Tübingen (Cotta) in 1810, and a French edition (up to the year 1742) came out in the same year in Braunschweig (Viehweg). In 1828 was published an English translation of the book, in two volumes, with the title Memoirs of Federica Sophia Wilhelmine, Margravine of Bareith, sister of Frederic the Great. Written by herself. Translated from the original French (the translation belongs to the series Autobiography. A collection of the most instructive and amusing lives ever published, written by the parties themselves, vol. 20). On the authenticity of the different editions cf. Pertz, Über die Denkwürdigkeiten der Markgräfin von Bayreuth.

${ }^{11}$ On Wilhelmine's relation to the philosophical scene of the time, in particular with the French culture, see Bracker, Markgräfin Wilhelmine von Bayreuth und die geistige Welt Frankreichs; on her artistic engagement, see Müller-Lindenberg, Wilhelmine von Bayreuth: Die Hofoper als Bühne des Lebens. On this topic one might also consult the very useful thesis by Barthel, Markgräfin Wilhelmine von Bayreuth und die historischen Bücher ihrer Bibliothek.
} 
the University of Erlangen-Nürnberg, which has recently undertaken the massive project of digitizing them. ${ }^{12}$

C5.P8 In fact, Wilhelmine shared with her favourite sibling a great passion for that intellectual world so thoroughly despised at the court of their father. According to 'an almost forgotten recipe, they brought together German firmness of spirit and French grace. ${ }^{13}$ In their intellectual inclination the siblings could enjoy the support of their mother Sophia Dorothea, who not only provided them with the best literary and scientific education, but also-dreaming of a future for her daughter at the more refined and cultivated British court-made her learn French and English so well that, according to direct sources, she was able to speak and write flawlessly in both languages, languages which Wilhelmine, like her mother and brother, preferred to the barbaric coarseness of the German vernacular. This aversion towards the rude figure of the father, against his military obsession and his cultivation of what might be called a thorough 'Germanity' has often been read, in a psychoanalytical vein, as the reason behind the almost pathological xenophilia of Frederick and (to a lesser extent) of his sister.

C5.P9 Yet, despite the glorious ambitions of Sophia Dorothea, the Soldier King arranged for Wilhelmine's marriage to a German hereditary prince, Frederick of Brandenburg-Bayreuth, a member of the House of Hohenzollern and descendant of the House of Habsburg. The marriage was clearly arranged in order to strengthen the relation between the relatively young kingdom of Prussia and the Holy Roman Empire. Fortunately, the marriage, which took place in 1731, was not as bad as Wilhelmine had feared as her betrothed was himself a man of great ambition, who wanted to develop the rural and provincial mark of Bayreuth and make it into one of the cultural centres of the Empire. When Wilhelmine's spouse came into his inheritance in 1735, the pair set about making Bayreuth a miniature version of Versailles. Their building projects included the restoration of their summer residence (known as the 'Hermitage'), the rebuilding of the great Bayreuth opera house, and the construction of a second, new opera house; the building of a theatre; and the reconstruction of the Bayreuth palace; all classical examples of the so-called Bayreuth Rococo style of architecture still renowned today. But the cultural engagement of the couple found one of its more remarkable realizations in the foundation of the University of Erlangen, in which especially Wilhelmine and her loyal advisor Superville played a strategic role.

C5.P10 In order to understand Wilhelmine's contribution to the German Enlightenment one should thus take into account both her private and her institutional engagement, where the former concerns her personal philosophical

\footnotetext{
${ }^{12}$ Wilhemina's collection is found under the Signatur: H58/EZ-II 1045. On the library's digitization project, see, URL = https://www.archiv.ub.fau.de/historischer-bestand-digital/Wilhelmine-vonbayreuth.shtml.

${ }^{13}$ Kolb, 'Nachwort' to Wilhelmine von Bayreuth, Die Memoiren, p. 544.
} 
interest, her philosophical ideas, and her position within the philosophical debates of the time, and the latter her concrete commitment to promoting a specific idea of philosophy through her advantaged 'social' position. I will consider these aspects in turn.

\section{The Philosopher-Princess}

C5.P11 Among the many talents Frederick recognized in his older sister, with whom-as he wrote in a flattering tone-'one could talk to at great length about the most disparate subjects, about war, about politics, and about coiffure, ${ }^{14}$ was a natural inclination towards 'philosophy', that is, towards an autonomy in thinking and acting that shied away from prejudice, and towards a practice of virtue that presupposes a clear idea of what is to be pursued and what not. Frederick never missed a single occasion to stress the philosophical inclination of his talented sister. In his History of the Seven Years War written right after Wilhelmine's deathwhich happened to occur on the same day as one of his most ruinous military defeats-he presents this attitude of hers in the following passage:

C5.P12 A princess of uncommon merit, with a cultivated understanding, a mind adorned with very superior knowledge, a genius apt at all things, and a singular talent for the arts.... Her excellent qualities, her generous and benevolent inclinations, her noble elevation of soul, the gentleness of her character, all united in her the brilliant advantages of wit with the unshaken virtues of the hearth.... The king and this worthy sister were accustomed to the most tender and constant friendship, from love that was formed in early infancy, that had been strengthened by the same education, the same feelings, and which fidelity unshaken rendered indissoluble.... She died, on the 14th of October 1758, with a courage and fortitude of soul worthy of the most intrepid philosophers. ${ }^{15}$

C5.P13 The funeral monument he erected in her honour in Sanssouci portrays his sister in the typical pose of the thinker absorbed in reflection, and is therefore called the 'Prinzess-Philosophin'. Voltaire himself, whose pen was-as Heine would express it-'a guillotine for any name of repute [eine Guillotine für jeden guten Namen]' had a great opinion of the princess whom he praises in a short ode addressed to the sovereign as a 'une famme sans préjuges, sans vice et sans mollesse. ${ }^{16}$

${ }^{14}$ Quoted in Kolb, 'Nachwort' to Wilhelmine von Bayreuth, Die Memoiren, p. 543.

15 Frederick II of Prussia, Histoire de la guerre de sept ans, chapter 9, pp. $252 \mathrm{f}$.

${ }^{16}$ Voltaire, Letter nr. 2739 (December 1758), in Oeuvres complètes, Vol. 28, p. 215. Cf. also his letter to the Duchess of Saxe-Gotha on 25 December 1758: 'Votre Altesse sérénissime connaissait-elle Mme la margrave de Baireuth? Elle avait beaucoup d’esprit et de talents: je lui [le Roi de Prusse] étais 
C5.P14 Unfortunately, since Wilhelmine never wrote any particular philosophical work, it is difficult to gain a coherent picture of her philosophical position. Nevertheless, it is possible to collect a few clues through considering some direct and indirect sources. Unsurprisingly, one interesting source turns out to be Wilhelmine's intellectual exchange with Voltaire, which saw one of its most remarkable episodes in November 1752, when Voltaire sent her the first draft of the poem Sur la religion naturelle (1756), originally dedicated to Frederick the Great and then published in a slightly different version, and with a new dedication to Wilhelmine. ${ }^{17}$ In the poem, occasioned by the publication of La Mettrie's Anti-Sénèque, Voltaire compares the universal moral law which is present in each person to the physical laws that rule the course of the universe. They are both a kind of loi naturelle, and since all that is 'nature' comes from God, the idea of justice and of moral conscience are likewise innate, essential and unchangeable in every human being. Far from being a Lamettriean machine-man, Voltaire's man is a moral subject who enjoys the freedom to follow or reject the prescriptions of the moral law. This innate presence of the idea of justice and of a moral conscience are even presented as the unique proof of the existence of God. ${ }^{18}$

C5.P15 The idea that these two 'virtues' are innate is at the centre of the comments on the lyrics that Wilhelmine sent to Voltaire on 1 November $1752 .{ }^{19}$ Stressing a central point of Voltaire's thesis, she remarks that if the idea of justice and the moral conscience were essential properties of human beings, then each of us could not avoid acting in accordance with them-which is of course contradicted by daily experience. Siding with a slightly Hobbesian position, Wilhelmine rather suggests that those virtues are not 'natural' in the sense of 'innate' and 'essential' as such, being instead nothing but 'capacities' every individual can develop only 'accidentally' in society. In fact, justice can emerge only by means of social laws, which assure a safe conduct of life which is impossible in the precarious and dangerous conditions of the state of nature. Under the pressure of their sole 'innate' and 'essential' sentiments-'the aversion from pain and the love of pleasure [l'aversion des peines et l'amour du Plaisir] ${ }^{20}$ - human beings enter society, and only then have the chance to become just, and gain a moral conscience.

très-attaché, et elle ne s'est pas démentie un moment à mon égard' (Letter 3729, in Oeuvres complètes, Vol. 39, p. 561). On the relationship between Wilhelmine and Voltaire see in particular the dated but still useful work by Horn, Voltaire und die Markgräfin von Bayreuth. Cf. also Mass, 'Voltaire und Wilhelmine von Bayreuth'

${ }^{17}$ On the history that lies behind the double publication of Voltaire's poem, and on the very convincing hypothesis that the poem was meant to be dedicated to Luise Dorothea von Meiningen, Duchess of Saxe-Gotha-Altenburg, rather than to Wilhelmine, see the insightful paper by Kulenkampff, 'Pöeme sur la Religion Naturelle. Anmerkungen zu einem Voltaire-Druck in der Bibliothek der Wilhelmine von Bayreuth'

${ }_{18}$ Voltaire, Pöemes sur la Religion Naturelle, et sur le Destruction de Lisbonne, pp. $32 \mathrm{f}$.

19 Letter D5059, in Voltaire, Oeuvres complètes, vol. 97, pp. $227 \mathrm{f}$.

${ }^{20}$ Ibid. For a detailled analysis of the exchange between Voltaire and the Margravine on this topic, cf. Kulenkampff, 'Pöeme sur la Religion Naturelle. Anmerkungen zu einem Voltaire-Druck in der Bibliothek der Wilhelmine von Bayreuth' 
C5.P16 In defending the same 'Hobbesian-Spinozistic' position Voltaire was criticizing in his poem, ${ }^{21}$ Wilhelmine affirms once more her intellectual independence. In fact, far from being a merely passive respondent to Voltaire's provocations, Wilhelmine clearly defends her own ideas, which likely contributed to Voltaire's high opinion of her. Among the constrasts between their orientations, it bears noting that the Margravine was, from the beginning, a passionate supporter of Wolff's philosophy at the Prussian court-an allegiance she shared with her brother-a fact that is of course rather surprising given that it was her father who had ordered the ban of Wolff's philosophy as a result of the charges presented by the Pietist opponents. ${ }^{22}$ Frederick's initial enthusiasm for Wolff's German Metaphysics is well-known: he was introduced to it by the then counsellor at the Prussian court, former Saxon diplomat and spy at the Habsburg Court, Ernst Christoph von Manteuffel (1676-1749). Manteuffel, without question the most prominent supporter of Wolffianism in the entourage of the Prussian Crown Prince, suggested to him that he read the book where he would find 'all that a philosopher can say that is most convincing about the very relevant topics in metaphysics.'23 The enlightened sovereign's admiration for Wolff's philosophy led him to order a French translation of that work-the manuscript of which has recently been identified ${ }^{24}$ - not only with the purpose of understanding it better himself, but also in order to make it accessible for Voltaire. On 7 May 1736, that is, still in the middle of the affaire between Wolff and the Pietists, Frederick praises Wolff as the initiator of a new era in philosophy:

C5.P17 The philosophy of Descartes was very good forty years ago; but now that Newton and most of all the famous Wolff have put the finishing touches to it, Descartes does not come into question any longer, and his philosophy is as outdated as the music by Attilio [Attilio Ariosti, musician at the Berliner Hof] in comparison with the one by Graun [Carl Heinrich Graun, Kappelmeister at Friedrick's court]. ${ }^{25}$

C5.P18 In fact, from the late 1730s it was Manteuffel who played a central role in defending the cause of Wolff at the Berlin court after his banishment from Prussia in 1723 , as well as in promoting the principles of his philosophy. In 1740, Frederick

${ }^{21}$ Voltaire, Pöemes sur la Religion Naturelle, et sur le Destruction de Lisbonne, p. 13.

22 On the famous controversy cf. Beutel, 'Causa Wolffiana. Die Vertreibung Christian Wolffs aus Preußen 1723 als Kulminationspunkt des theologisch-politischen Konflikts zwischen halleschem Pietismus und Aufklärungsphilosophie'.

${ }^{23}$ Manteuffel's letter to Brühl, April 24, 1736 quoted in Neumann, 'Der preußische Kronprinz Friedrich und die französische Übersetzung der Deutschen Metaphysik Christian Wolffs im Jahr 1736'.

${ }^{24}$ Cf. Neumann, 'Der preußische Kronprinz Friedrich und die französische Übersetzung der Deutschen Metaphysik Christian Wolffs im Jahr 1736'.

${ }^{25}$ Frederick II of Prussia. Correspondence de Frédéric avec sa soeur Wilhelmine, margrave de Bayreuth, letter no. 37 . 
fully rehabilitated Wolff, who at the end of the same year returned triumphantly to Halle. However, the efforts of Manteuffel, and of the Berlin provost Johann Gustav Reinbeck and of other members of the Societas Alethophilorum-a society of 'friends of Wolffian philosophy' Manteuffel had founded in Leipzig ${ }^{26}$ - to promote Wolff's ideas more broadly in Prussia were thwarted by Voltaire, with whom Frederick had engaged in a personal and intellectual friendship since 1736, although there would be several twists and turns over the forty years of its duration. ${ }^{27}$

C5.P19 When Voltaire arrived in Prussia (in 1736) he had already begun his apprenticeship in Newtonian science that would lead to the publication of the Éléments de la philosophie de Newton (1738), that he dedicated to Émilie du Châtelet who played a central role not only in the realization of the work, but also in Voltaire's final conversion to what has been called his 'Newtonian religion. ${ }^{28}$ In his campaign in favour of the new science, Voltaire developed a clear intolerance toward the dogmatic edifice of the Wolffian system, and toward its insistence on the logical-ontological grounds of every item of metaphysical, practical, and natural knowledge. It was, in fact, Voltaire who managed to dissuade Frederick from calling Wolff to the head of the Academy of Sciences in Berlin, instead offering the presidency to one of the most brilliant representatives of the French scientific milieu, Pierre Moreau de Maupertuis (1698-1759), who-together with Leonhard Euler (1707-1783), Director of the Mathematical class-would accomplish the remodelling of the Academy on the model of the English cultural world and conversion to the Newtonian science which heralded, as its consequence, the final defeat of the supporters of Wolff's system. ${ }^{29}$

C5.P20 During the years of this French 'invasion' of the Academy, which Frederick had intentionally promoted, and during the ensuing anti-Wolffian campaign, Voltaire's astute guidance led the sovereign to progressively develop a mistrust of the capacity of reason, and to replace Wolffian rationalistic optimism with a sceptical attitude particularly inspired primarily by the reading of Montaigne and Bayle. Claims such as 'l'homme est plus sensible que raisonnable,, ${ }^{30}$ or 'l'homme est fait pour agir, et non pas pour contempler' ${ }^{31}$ reveal the unambiguous influence

\footnotetext{
${ }^{26}$ On the Societas Alethophilorum and on the role of Manteuffel in the circulation of Wolffianism cf. Bronisch, Der Mäzen der Aufklärung. Ernst Christoph von Manteuffel und das Netzwerk des Wolffianismus.

${ }_{27}$ Cf. Mervaud, Voltaire et Frédéric II: une dramaturgie des lumières 1736-1778.

${ }^{28}$ Cf. Vaillot, Avec Mme du Châtelet (1734-1749), pp. 71-92. On the scientific and philosophical engagement of du Châtelet cf. Hagengruber (ed.), Emilie du Châtelet between Leibniz and Newton; Brading, Émilie Du Châtelet and the Foundations of Physical Science.

${ }^{29}$ On the reception of Newton in early eighteenth-century Germany, cf. Calinger, 'The NewtonianWolffian Controversy: 1740-1759'; Casini, 'Newton in Prussia'; and Ahnert, 'Newtonianism in early Enlightenment Germany, c. 1720 to 1750: Metaphysics and the critique of dogmatic philosophy'.

${ }^{30}$ Frederick to d'Alembert, 8 September 1782, Oeuvres de Frédéric le Grand, vol. 25, p. 264.

${ }^{31}$ Frederick to Voltaire, 17 February 1738, Oeuvres de Frédéric le Grand, vol. 21, p. 184.
} 
of Voltaire and become a sort of refrain in Frederick's private and public reflections. ${ }^{32}$ But even later on, despite the influence of Voltaire, Frederick kept on looking at Wolff as an important, albeit now a distant, source of philosophical inspiration, and the same holds for his sister. As is revealed in an exchange between Wolff and Manteuffel, in September 1747 she paid a visit to Wolff, who by that time had been gloriously re-installed in Halle. According to Wolff's letter, the Margravine, together with the Herzog of Wolfenbüttel and his wife, and the inseparable Superville-who was, according to Wolff, 'very competent in philosophy'-went to see him in order to discuss a very specific question: namely 'the way in which the ideas of corporeal things (ideae rerum sensibilium) arise in the mind and their similarity to the objects they represent.' Besides that, the report continues, '[they] came to speak of the fact that the consciousness of what happens in the soul cannot occur in any material thing. ${ }^{33}$

C5.P21 Significantly, Wilhelmine's interests concerned very technical philosophical questions, and were not at all the fruits of a dilettantism on her part. Indeed, from the topic of the ideas of corporeal things and their relation to the represented objects, Wilhelmine's question proceeded straight to the very controversial point of thinking matter. Wolff replied explaining once again what he had argued in his German Metaphysics and in the later Psychologia rationalis: the difference between the representations that occur in a simple being like the soul, and the ones that belong to a composite being like the body consists in the fact that the first ones are the result of the capacity the soul has to reduce the multiplicity of the represented object to the unity of consciousness. Bodies lack this capacity. Indeed, as opposed to what happens in the soul, the repraesentationes compositi in composito, like the images in a mirror or in a painting, do not present any reductio ad unum: the subject in that case is not different from its object, it cannot recognize its object as something different from itself, and cannot compare it with others, since a material subject cannot represent more than one object at a time, where all this would be required in order to be conscious of representations. Simplicity is therefore for Wolff the necessary condition for consciousness, and thus for thought. ${ }^{34}$ This was, in fact, Wolff's last word on the contested question of materia cogitans, a question that at that time was perceived-as Leibniz claimed in his first letter of

${ }^{32}$ On Frederick's philosophical engagement and on the different phases of its development cf. Mori, 'Federico II e la cultura illuministica'.

${ }^{33}$ Wolff to Manteuffel, 10 September 1747, letter 370 in Middell and Neumann (eds), Historischkritische Edition des Briefwechsels zwischen Christian Wolff und Ernst Christoph Graf von Manteuffel.

${ }^{34}$ Cf. Wolff, Vernünftige Gedanken von Gott, der Welt und der Seele des Menschen, auch allen Dingen überhaupt, \$\$217, 740-1, and 751; and Wolff, Psychologia rationalis, \$83. On this topic cf. Rumore, 'Die Bilder der Seele. Vorstellung und Einheit'. On the debate about this topic in eighteenthcentury Germany, cf. Rumore, Materia cogitans. L'Aufklärung di fronte al materialismo. 
the correspondence with Samuel Clarke-as an embarrassing legacy of Locke's Essay and which Clarke himself seemed to look on with condescension. ${ }^{35}$

C5.P22 Wilhelmine was well aware of the fact that the topic of thinking matter that she was discussing with Wolff was closely related to another hotly debated topic, one which was at that moment at the centre of philosophical debate in Germany. In fact, the question of the divisibility of matter, which is to say the question of the validity of the monadology, had been the subject of the Berlin Academy's prize-essay competition of that year. The Academy in Berlin had announced in 1746 a competition on that topic, that had been somehow anticipated by an anonymous text published by Euler just shortly before. His Gedanken von den Elementen der Körper (Thoughts on the Elements of Bodies) were a clear attack on the doctrine of monads on the basis of its incompatibility with the principles of rational mechanics, and the text was perceived as an even clearer declaration of war from the side of the supporters of the Newtonian science against the Wolffian front in the Academy. The prize was subsequently awarded to Johann Heinrich Gottlob Justi (1720-1771), whose essay followed the line of Euler's refutation. Moving far beyond the boundaries of that strictly academic debate, the controversy represented an official attack on the principles of the so-called Leibniz-Wolffian philosophy, and a way of putting into question its compatibility with the new trends in natural philosophy. The episode reached the public sphere, further exacerbating the oppositions between the opposed philosophical sides that had already been established in German academia. ${ }^{36}$

C5.P23 On this basis, it seems pretty clear that the topic Wilhelmine chose for her conversation with Wolff was not accidental; it testifies once more to her deep acquaintance with the current debate, and offers evidence of her genuine philosophical interests. Indeed a few years before visiting Wolff-that is, a few years before the explosion of the Monadenstreit in Berlin-in 1743 Wilhelmine participated with her husband in the inauguration of the University of Erlangen. On that occasion she sponsored a debate that shows her familiarity with the most technical philosophical topics but also, and more importantly, betrays a conception of 'philosophy' on her part that goes beyond the boundaries of mere

\footnotetext{
${ }^{35}$ Cf. Yolton, Thinking Matter. Materialism in Eighteenth Century Britain; and Thomson, Bodies of Thought. Science, Religion, and the Soul in the Early Enlightenment. On the debate in France cf. Thomson, L'âme des lumières. Religion, science et politique au siècle des Lumières (1690-1760).

${ }^{36}$ The importance of the competition has been deeply investigated by the scholarship. Cf. Palaia, 'Berlino 1747: il dibattito in occasione del concorso dell'Accademia delle Scienze'; Pasini, 'La prima recezione della monadologia. Dalla tesi di Gottsched alla controversia sulla dottrina delle monadi'; Neumann, Zwischen Materialismus und Idealismus; Neumann (ed.), Monaden im Diskurs: Monas, Monaden, Monadologien (1600 bis 1770); and Rumore, 'Monaden und Materialismus. Euler und Ploucquet über die denkende Materie'. For a focus on the public dimension of the debate cf. Goldenbaum, 'Das Publikum als Garant der Freiheit der Gelehrtenrepublik'; and Broman, 'Metaphysics for an Enlightened Public: The Controversy over Monads in Germany, 1746-1748'.
} 
academic controversy, in the direction of the Enlightenment ideal of Selbstdenken, or the autonomous and courageous usage of one's own understanding.

\section{The Conflict of the Faculties at the University of Erlangen}

C5.P24 The founding of the University of Erlangen-the Friedrich-AlexanderUniversität-was one of the main goals of the cultural reconstruction of the mark of Brandenburg-Bayreuth undertaken by Wilhelmine and her husband. The presence of a university in a margraviate was an important step towards the (political and economical) independence of that borderland from the supremacy of the Empire. Indeed it is well-known that the idea and the role of the university at that time was very different from the one we have today; a good record is offered by Kant in his Conflict of the Faculties, where he presents the university as the institution in charge of training civil servants, that is, physicians, jurists, and clergymen. Those people were serving their country, or, as Kant puts it, they were trained in the 'private' use of reason since they had to obey what was established by the sovereign: the accepted corpus of medical writings, the corpus iuris, and the Bible. The only faculty which was (relatively) free from the sovereign authority was the philosophical one, which was therefore considered inferior, and which trained its members in the 'public' use of reason, the one that all human beings share insofar as they are human. ${ }^{37}$ The sovereign, the prince, or (as in this case) the Margrave had a big advantage in having his own university at his disposal: he could train up his civil servants as he liked, he could improve the cultural prestige (and therefore the political power) of his region, and last but not least, he could fill his coffers by attracting students from abroad. ${ }^{38}$ All these considerations were at the origin of the idea to promote the foundation of a local university; but what is remarkable about that event is precisely the role Wilhelmine played in the inauguration of the institution, which took place in the first week of November 1743 and represents a truly unique episode in the German world.

C5.P25 The opening ceremony is described in full detail in two histories of the University of Erlangen published shortly after the founding of that institution. The first one is the Historia Academiae Fridericianae Erlangensis by Johann Wilhelm Gadendam, published soon after the event itself in 1744; the second is the Geschichte der Königlich Preussischen Friedrich-Alexanders-Universität zu Erlangen von ihrem Ursprung bis auf gegenwärtige Zeiten, published fifty years later (in 1795) by Georg Wolfgang Augustin Fikenscher. Both Gadendam and

\footnotetext{
37 The distinction between the 'public' and 'private' use of reason is, of course, at the core of Kant's Enlightenment manifesto, 'Beanwortung der Frage: Was ist Aufklärung?'

${ }^{38}$ Cf. Wachter, 'Markgraf Friedrich von Brandenburg-Bayreuth als Universitätsgründer'; cf. also the rich contribution by Zimmermann, Friedrich der Jungere, Markgraf von Bayreuth, Stifter der Universität Erlangen.
} 
Finkenscher linger over an episode they must have held to be truly exceptional. As they describe it, on the 6 November, after a set of Latin prolusions held by the three deans of the higher faculties, and followed by that of Georg Wilhelm Poezinger, the dean of the Philosophical Faculty,

C5.P26 the Margravine Wilhelmine expressed the desire to hear a disputation in German; she chose three professors, the pro-chancellor Gadendam as Defendent and professor Huth and Braun as Opponenten; then she communicated to them the topics they had to debate and gave them one hour to organize their speeches. This short time was meant in order to provoke a lively discussion that would let their real philosophical skills emerge, instead of one of the usual tedious academic debates that follow from a long and accurate preparation. ${ }^{39}$

C5.P27 The names of Johann Wilhelm Gadendam (whom we have already mentioned as the author of the first history of that university), Carl Adolph Braun, and Caspar Jakob Huth are today nearly completely forgotten. Nor do we find much help in determining their identities through reference to the catalogue of the professors and lecturers at the Friedrich-Alexander-Universität, as it only confirms that they were all professors at the newly founded university, that they all had (as every professor did) an education in philosophy, and that they were teaching classes in law, history, and theology. ${ }^{40}$ Only Gadendam was professor in the philosophical faculty, where he taught universal history and natural law. In general, the catalogus praelectionum reveals that in the philosophical faculty there was a hegemonic presence of Wolffians: the courses in metaphysics, logic, practical philosophy all referred to Wolff's works (or, in some few cases, to those of his student Ludwig Philipp Thümmig). Nevertheless there is one important source through which we can gain some relevant information about these individuals, and-what is more important in this context-to understand the reasons behind Wilhelmine's selection, namely, a report Wilhelmine sent to her brother the king just a couple of months after the inauguration (on 11 November) where she declared that on that occasion 'the defender of the theses [Gadendam] was a supporter of Newtonianism, whereas his opponents [Huth and Braun] were supporters of Wolff: ${ }^{41}$

C5.P28 The idea to bring together in a direct disputation the two main conflicting parties within the German intellectual scene was already remarkable in itself. But it seems even more audacious if one considers the subjects of the theses Wilhelmine

\footnotetext{
39 Fikenscher, Geschichte der Königlich Preussischen Friedrich-Alexanders-Universität zu Erlangen von ihrem Ursprung bis auf gegenwärtige Zeiten, p. 290.

${ }^{40}$ Wittern-Sterzel et al. Die Professoren und Dozenten der Friedrich-Alexander-Universität Erlangen 1743-1960, Vol 1: Theologische Fakultät, Juristische Fakultät.

${ }^{41}$ Frederick II of Prussia, Friedrich der Große und Wilhelmine von Baireuth, Vol. 2: Briefe der Königszeit 1740-1758, p. 64.
} 
placed at the centre of the debate. The first one was: Corpus cogitans adeo non repugnare sibi, ut concipi nequeat ('The concept of a thinking body is not contradictory in itself, and it is not unconceivable'); the second one: Haud absurdum videri opinionem eorum, qui, corporum principia composita esse, adserunt ('The opinion of those who claim that the elementary parts of bodies are composite is not absurd at all'). Besides the short notice, and the mandatory request to dispute in German, Wilhelmine added as an additional condition of the debate the impossibility of drawing on arguments from Scripture. According to the sources we have, the debate was incredibly lively and was carried on for many hours: the inauguration of the new university could not have been more impressive. With his usual ironic taste, Frederick commented thus on the choice of his sister: 'I tremble to see those savants engaged in such a debate. I wonder where you all will end up, if you start with the investigation of the divisibility of matter. ${ }^{32}$

C5.P29 A source from 1844 stresses that the key to understanding Wilhelmine's choice of topic lies in her own Wolff-oriented philosophical ideas. ${ }^{43}$ In effect, both the theses were at the core of the philosophical debate of the time. And on separate occasions Wilhelmine revealed that she took inspiration from a conversation she had with Voltaire when he joined Frederick in his trip to Erlangen in 1743. The conversation concerned Voltaire's doubts about the spirituality of the soul, an idea that was at the basis of the Thirteenth of his Philosophical Letters, and which was also expressed-in a much more radical form - in the so called 'Epistula gallica' that the Wolffian Johann Gustav Reinbeck had just published in a German translation a few years before (in 1739), as an appendix to his defence of the thesis of Wolff's rational psychology concerning the topic of immortality. Even if Reinbeck cautiously presents the letter, 'in which it is claimed that matter can think', as an 'anonymous writing', he implicitly suggests that its proximity to Voltaire's claims in the Letter on Locke seems to suggest his authorship. ${ }^{44}$ That Voltaire was actually the source of inspiration for Wilhelmine's choice of the topics of the debate must have been clear to her contemporaries. In fact, one of the disputants, the Wolffian Huth, who was asked to refute the thesis of the infinite divisibility of matter, suggests in a short report that 'Voltaire's scepticism about the spirituality of the soul,

\footnotetext{
${ }^{42}$ Frederick II of Prussia, Correspondence de Frédéric avec sa soeur Wilhelmine, margrave de Bayreuth, Vol. 27/1, letter no. 137 (21 November 1743).

${ }^{43}$ According to Zimmermann (Friedrich der Jungere, Markgraf von Bayreuth, Stifter der Universität Erlangen, p. 61), Wilhelmine was 'a thoughtful princess, well-acquainted with the Wolffian philosophy, a fact that is made manifest in the propositions which the "Pallas of Bayreuth" set out for the disputation she occasioned'.

${ }^{44}$ The work by Reinbeck is: Philosophische Gedancken über die vernünfftige Seele und derselben Unsterblichkeit. Nebst einigen Anmerckungen über ein Frantzösiches Schreiben, darin behauptet werden will, daß die Materie dencke. On the topic cf. Rumore, Materia cogitans. L'Aufklärung di fronte al materialismo, pp. 218-28.
} 
and the arguments that were used for and against his theses, gave our venerable and wise Margravine the idea to choose those topics for the public discussion. ${ }^{34}$

C5.P30 The idea of inviting both supporters of the Wolffian and of the Newtonian parties to a confrontation on topics related to the highly contentious question of materialistic atomism was not banal. In a larger frame it can be seen as the attempt to bring to a direct confrontation - which had to be held in German, in a limited number of hours, and with no references to any form of authority except reason itself-the old German metaphysical tradition and the new French 'naturalistic' orientation in philosophy. Such an attempt secures an exceptional place within the cultural scene of the Aufklärung for Wilhelmine. As Huth expresses it in the previously mentioned report, which was promptly translated into French, ${ }^{46}$ she was

C5.P31 [a] Princess who, thanks to her grand Esprit has become the Queen of all the people of her gender [de toutes les persones de son sexe]. For it is true that what Great Britain can admire in the genius of their immortal [Queen] Caroline, we can admire today in the genius of our incomparable Wilhelmine.... The former founded a university in Göttingen, the latter one here [in Erlangen]; the former was so amused by philosophical meditations to invite the two most prominent philosophers of her time to her court, i.e. Leibniz and Clarke, in order to let them discuss in writing the most thorny topics in metaphysics; the latter shows the same engagement in philosophical questions, and pushes her love for art and science just as far. ${ }^{47}$

C5.P32 Huth's implicit comparison of himself to Leibniz (and maybe also Gadendam to Clarke) may betray a certain lack of modesty on his part, but the sense of his words seems clear insofar as they express the highest admiration for the authenticity of Wilhelmine's philosophical engagement, and for her daring to arrange, in a newly founded university, a debate that aspired to reach well beyond the boundaries of merely local academic concerns.

C5.P33 Even if the lack of a systematic philosophical work by Wilhelmine makes it difficult to gain a detailed picture of her Weltanschauung, the way she deals with the philosophical controversies of the time nonetheless reveals a deep engagement in promoting the cause of the Enlightenment through facilitating and participating in the main cultural debates of the eighteenth century. The view that the fact that an opinion might be theoretically controversial should not be a hindrance to rational dialogue and public dispute is the premise of her courageous defence of

\footnotetext{
${ }^{45}$ Huth, Nachricht von der Einweihung und dem gegenwärtigen Zustande der Friedrichs Universität Erlangen, p. 27.

46 The complete title is: Lettre de Mr C. J. Huth à un ami touchant l'inauguration et l'état present de l'Université fredericienne d'Erlang.

${ }^{47}$ Huth, Nachricht von der Einweihung und dem gegenwärtigen Zustande der Friedrichs Universität Erlangen, p. 26.
} 


\section{OUP UNCORRECTED AUTOPAGE OOFS - FIRST PROOF, 09/02/21, SPi}

WILHELMINE OF BAYREUTH AND THE GERMAN ENLIGHTENMENT

109

the libertas philosophandi and of her campaign for toleration. There is no doubt that she played a pivotal role in turning what had been up to that point the rather provincial milieu of Bayreuth into one of the main Zentren der Aufklärung. And in so doing she promoted an idea of philosophy that went beyond the boundaries of academic professionalization, and that-according to the most noble German tradition-had to be rather understood as the highest form of Weltweisheit, a guidance for good conduct in both understanding and life. It was her way of contributing to the realization of the ideal of the 'enlightened era', an era inaugurated by her brother and later celebrated by Kant as the time of the flourishing of Selbstdenken, as a result of which Wilhelmine is rightly accorded the title of the female Prometheus, who has kindled the light of the Enlightenment in Franconia. ${ }^{48}$

${ }^{48}$ Kulenkampff, 'Ob Materie denken könne’: Wilhelmine von Bayreuth und die Aufklärung, p. 5. 